\title{
In the Name of Independence: with Regard to Practicing Non-Audit Service by External Auditors
}

\author{
Mahdi Salehi (corresponding author) \\ Accounting and Management Department, Zanjan University \\ D.N. 1, Naghilo Alley, Emam Street, Hidaj City, Zanjan Province, Iran \\ Tel: 98-91-2142-5323_E-mail: Mahdi_Salehi54@yahoo.com
}

\begin{abstract}
External auditors are very important for third partite because they add credibility to financial statements and third party can make decision in accord of financial statement audited. In recent years, the auditing and accounting profession faced scrutiny because of auditing scandals. Recent high profile accounting controversies such as Enron and World have highlighted the continuing debate about whether and how auditors can be independent of their clients (Kosmala, 2003). In the view of the fact, now a days because of non-audit services, the audit practice is questionable, whereas third parties believe that without independence, there is no value for accounting and auditing practices. In this paper the author concluded that the non-audit services impair audit independence and audit objectivity.

In this situation, the author believes that both the professional and academic should be redefined non-audit services and also limited such services for audit and accounting professions; therefore national and international professions should be taken more reactions regarding to clarify of non-audit services to auditors as well as third parties.
\end{abstract}

Keywords: Auditor, Independence, Non-Audit Services (NAS)

\section{Introduction}

The potential conflicts of interests among owners, managers, and other security holders create an environment in which an outside auditor may contribute significant value to investors. So, the demand for auditing arises from the potential conflict of interest that exists between owners and managers.

The contractual arrangement between these parties normally requires that management issue a set of financial statements that purports to show financial position and results of operation of the entity. In order to properly evaluate the financial statements, the parties to the contract must agree on a benchmark or criteria to measure performance. Without on agreed upon criteria, it is impossible to measure the fair presentation of the financial statement. Therefore, external auditor plays vital rule in this condition. External auditor serves several purposes. It can act to monitor the performance of management on behalf of shareholders or as a demonstration by management to existing and potential shareholders of their effort and performance. The external system of audit, with its final product, the audit opinion, adds credibility to the financial statements so that users can rely on the information presented and, as a result, the entire system of financial reporting is enhanced.

However, during the last 30 years, the audit practice became undermine, because of practicing non-audit services, which many professionals, practitioners, and academic researchers have criticized the practice whereby external auditors providing non- audit service. The impairment or lack of auditor independence is a main cause of many corporate collapses and corporate scandals across the world, including the US case of Enron. Most of the concern has focused on the potential harm that the activity has had on the "appearance" of independence, as opposed to the loss of independence "in fact" (Terry, 1996). The failures of Enron and World Com, both among the major industrial players in the world, and the subsequent collapse of Anderson, one of word's largest accounting firm, has prompted the global corporate society to reconsider the dependability of accounting and audit professionals in providing their services. Many have started to re-evaluate the level of trust they put to audit as to provide assurance for investment and financial information, and the trend of solely depending on audit as the best source of credibility for such information may have now become defunct. In this paper the author briefly explain about independence as well as factors affecting to independence, and factors affecting to independence, which the author focused on non-audit services.

\section{Independence}

One of the key factors of the auditor's is independence, without independence users of financial statements cannot rely on the auditors report. In short, the external system of audit, with its final product, the audit opinion, adds credibility to 
the financial statements so that users can rely on the information presented and, as a result, the entire system of financial reporting enhanced (Sucher et al 2004). Furthermore, independence is the core of this system.

The concept of audit independence is fuzzy, the rules governing it are complex and burdensome, and a reexamination is long overdue (Elliott and Jacabson, 1992).

DeAngelo (1981) defined auditor independence as "the conditioner probability of reporting a discovered bridge".

Arens et al. (1999) defined "independence in auditing" as taking an unbiased viewpoint in the performance of audit tests, the evaluations of the results and the issuance of audit reports. Independence includes the qualities of integrity, objectivity and impartiality. Knapp (1985) states the independence in a different angle. He viewed it as "The ability to resist client pressure". According to Flint (1988)"Independence, therefore, is not a concept which lends itself to universal constitution prescription, but one for which the constitution prescription will depend on what is necessary to satisfy the criteria of independence in the particular circumstances".

The ISB (2000) defines independence as: Freedom from pressures and other factors that impair, or are perceived to impair, an auditor's willingness to exercise objectivity and integrity when performing an audit it is the absence of certain activities and relationships that may impair, or may be perceived to impair, an auditor's willingness to exercise objectivity and integrity when performing an audit.(ISB 2000: 44).

There are two approaches of audit independence have commonly been referred to as independence of fact and independence of appearance.

\section{1 independence: in fact and appearance}

According to Mautz and Sharaf (1964) there are two aspects of independence: firstly, the real independence of the individual practitioner in the performance of his/her works and secondly, the apparent independence of auditors as a professional group. These two concepts of independence have been referred to as 'practitioner independence' and 'professional independence' respectively.

Independence may be a state of mind or a behavior. According to AUP 32, independence requires a freedom from bias, personal interest, prior commitment to an interest, or susceptibility to undue influence or pressure (AUP, 2001). This suggests that an auditor possessing the requisite state of mind will act in the correct fashion. In this context, auditors should not be independent in fact, but more importantly they should be seen to be independent in examining and attesting clients' financial statements (Stevenson 2002). Precisely, auditors are expected to be able to independently decide on reporting strategies without any influence from their clients' management (Cullinan, 2004).

Orren (1997) states that independence in fact refers to the actual, objective relationship between auditing firms and their clients whereas independence in appearance is the subjective stated of that relationship as perceived by the clients and the third parties. Church and Zhang, (2002) argue that independence in fact is necessary to enhance the reliability of financial statements. On other hand, independence in appearance is necessary to promote public confidence such that users will rely on audited financial statements.

The issues of independence in fact and appearance have also been acknowledged by the standard setting bodies. The AICPA acknowledged the importance of perceptions of auditor independence- 'Independent auditors should not only be independent in fact; they should avoid situations that may lead outsiders to doubt their independence' (AICPA 2001). The current AICPA Code of Professional Conduct (1988) explicitly requires not only actual independence from audit clients but also the appearance of independence to third parties. The SEC defined independence in fact and independence in appearance as separate but equally necessary factors in establishing the auditor's objectivity and integrity when certifying financial statements filed with the commission by an issuer of securities (Olazabal and Alwer, 2001).

According to Mautz and Sharaf (1964), there are three dimensions of auditor independence which can minimize or eliminate potential threats to the auditor's objectivity:

(I) Programming independence includes:

Freedom from managerial interference with the audit program; freedom from any interference with audit procedures; and freedom from any requirement for the review of the audit work other than which normally accompanies the audit process,

(II) Investigative independence en com passes:

free access to all records, procedures, and personnel relevant to the audit; active co-operation from management personnel during the audit examination; freedom from any management attempt to specify activities to be examined or to establish the acceptability of evidential matter; and freedom from personal interests on the part of the auditor leading to exclusions from or limitations on the audit examination. 
(III) Reporting independence includes:

Freedom from any feeling of obligation to modify the impact or significance of reported facts; freedom from pressure to exclude significant matters from internal audit reports; avoidance of intentional or unintentional use of ambiguous language in the statement of facts, opinions, and recommendations and in their interpretations; and freedom from any attempt to overrule the auditor's judgment as to either facts or opinions in the internal audit report.

The immediate objective of the audit is to improve the reliability of information used for investment and credit decisions according to Elliott and Jacabson (1998) the principles of independence as follows:

Audit independence improves the cost - effectiveness of the capital market by reducing the likelihood of material bias by auditors that can undermine the quality of the audit. Therefore, they play vital role in economic sector. However, some factors may have negative affection to independence, which these factors should be identified by professionals and take sever action to reducing such a factors.

\section{Factors Affecting To Independence}

Several situations may impair the auditor's independence, such as contingent fee arrangements, gifts, auditor's with personnel or operations, non-audit services (NAS), outsourcing, opinion shopping, reporting relationships, and others.

Among the factors that affect to auditor independence that have been studied are:

(1) The effects of gifts (pany and Reckers, 1980);

(2) The purchase discount arrangement (pany and Reckers, 1980);

(3) The audit firm size (Shockley, 1981; Gul, 1989);

(4) The provision of management advisory services (MAS) by the audit firm (Shockley, 1981; Knapp, 1985; Gul, 1989; Bartlett, 1993; Teoh and Lim, 1996; Abu Bakar et al 2005);

(5) The client's financial condition (Knapp, 1985; Gul, 1989; Gul and Tsui, 1992);

(6) The nature of conflict issue (Knapp, 1985);

(7) The audit firm's tenure (Shockley, 1981; Teoh and Lim, 1996);

(8) The degree of competition in the audit services market (Knapp, 1985; Gul, 1989);

(9) The size of the audit fees or relative client size (Gul and Tsui, 1992; Bartlett, 1993; Teoh and Lim, 1996; Pany and Reckers, 1980);

(10) The audit committee (Gul, 1989; Teoh and Lim, 1996); and

(11) Practicing non-audit services (NAS) by auditors (Beattie et al, 1999 and Rayhunadan;2003).

In this paper the author only attempted to clarify non-audit services and its affection to independence of auditors.

The audit failures that have been reported have led to major criticism of the auditing profession worldwide by exposing the weaknesses of the profession in term of safeguarding shareholders' and stockholders' interests (Brandon et al, 2004, Citron, 2003, Cullinan, 20004, Fearnley and Beattie, 2004, Ghosh and Moon, 2005, Gwilliam, 2003, Higson, 2003, Krishnan and Levine 2005); thus some of this criticism arose from non-audit service practices by auditors.

\section{1 non-audit services (NAS)}

Non-audit services (NAS) may be any services other than audit provided to an audit client by an incumbent auditor. As the demand for business expert services grew over the late 20th century, public accounting firms expanded the scope of their services to include corporate and individual tax planning, internal audit outsourcing, and consulting related to mergers and acquisitions, information systems, and human resources. Recent concerns about auditor independence have focused on the provision of non-audit services to audit clients.

Today's public accounting firms have undergone dramatic changes in the last 25 years. Over the last decade the proportion of revenue of large public accounting firms derived from providing non-audit services grew from $12 \%$ to $32 \%$ (Public Oversight Board, 2000), suggesting that the economic bond between auditors and their clients strengthened over this time as auditors delivered more consulting-oriented services to their audit clients.

Based on the amounts reported in the Public Accounting Report, last year audit fees for the top seven accounting firms were approximately $\$ 9.5$ billion. These accounting firms audited over $80 \%$ of all registrants, and virtually every company with a large market capitalization. What's more, the audit and accounting fees of the largest accounting firms, as a percentage of their revenue, has decreased significantly from $70 \%$ of total revenue in 1976 for the Big Eight to 34\% of total revenue for the same firms in 1998. (Ashbaugh 2004) Given the shift in revenue streams of public accounting firms, it is important to discuss the services that audit firms provide. An accountant becomes a Certified Public Accountant (CPA) to engage in attestation services, that is, conduct audits. Scholars concern that benefits either from 
cost savings or from fees revenue increases can strengthen the economic bond between auditors and their clients, which can further threaten auditor independence

It is found out that auditors believe that the auditors' work would be used as a guide for investment, valuation of companies, and in predicting, bankruptcy; furthermore, the third party fell that there is strong relationship between the reliability of the auditor's work and the investment decision. An also the auditor's work facilitates the process of economic development through the presentation of reliable information concerning the financial position of the companies (Whadan et al, 2005); therefore, the main question that arises when auditors provide or could provide both audit and non-audit services is whether the auditors are able to conduct their audits impartially, without being concerned about losing or failing to gain additional services, and the subsequent economic implications for the audit firm (Lee, 1993). Auditors seek to provide NAS because of the considerable economies of scope that ensue, i.e. cost savings that arise when both types of service are provided by the same firm. These economies of scope are of two types: knowledge spillovers that originate in the transfer of information and knowledge; and contractual economies that arise from making better use of assets and/or safeguards already developed when contracting and ensuring quality in auditing.

As far as, globalization in accounting and assurance service has also created the multi disciplinary nature of large audit firms (Brierley and Gwilliam, 2003). These multi disciplinary firms offer audit and non-audit services to audit clients and this have become one of the major concerns regarding the potential auditor independence dilemma (Quick and Rasmussen, 2005).

- $\quad$ The prohibition of specified non-audit services is predicated on three basic principles:

- $\quad$ An auditor cannot function in the role of management;

- $\quad$ An auditor cannot audit its own work; and

- $\quad$ An auditor cannot serve in an advocacy role for its client.

The range of services now offered by the audit firms to both the public and private sector is wide. This may summarized as follows:

$\begin{array}{ll}\text { - } & \text { System, and IT; } \\ \text { - } & \text { Training; } \\ \text { - } & \text { Services for payroll; } \\ \text { - } & \text { Risk management advice; } \\ \text { - } & \text { Taxation, including tax compliance and tax planning advice; } \\ \text { - } & \text { Corporate recovery and insolvency; } \\ \text { - } & \text { Mergers and acquisitions services; } \\ \text { - } & \text { Transaction support and follow up; } \\ \text { - } & \text { Public offering; } \\ \text { - } & \text { Recruitment and human resources; and } \\ \text { - } & \text { Portfolio monitoring. }\end{array}$

Provision of some of these services may provide a real threat to independence in the case of audit client. The principal threats which arise from the provision of non-audit services are:

- $\quad$ Self interest: the increase in economical benefit dependence;

- $\quad$ Self review: taking management decisions and auditing one's work;

- $\quad$ Advocacy: acting for the client's management in adversarial circumstances; and

- Familiarity: becoming too close to the client's management though the range of services offered.

One of the fundamental importance in understanding the conflict of interest that arises from the provision of non-audit services to audit clients is the fact that is so doing the audit firm is really serving two different set of clients; management consulting services and the audit committee, shareholders and all those who rely on the audited financials and the firm's opinion in deciding whether to invest in the case of audit (Levine and Kornish, 2000). So, in these cases the credibility of external audit work will be questionable. In the Enron case, it has been widely reported that Andersen received $\$ 25 \mathrm{~m}$ in audit fees and $\$ 27 \mathrm{~m}$ for non-audit services. There have been many criticisms about the potential conflict of interest faced by audit firms who receive large consultancy fees from their audit clients. Concerns are expressed about how an auditor with a statutory responsibility to company shareholders can handle a commercial 
relationship with the company's management and remain impartial.

\section{2 management advisory system (MAS)}

Another item it also belongs to the non-audit services as well as highly affecting to the independence is management advisory system (MAS), which consist of advice and assistance to a client to improve capabilities and resources and achieve stated objectives. The accountant may conduct studies and counsel management in such matters as business organization, planning, controls, system's operations, personnel and finances. Management engagements require an investigation and analysis of the client's operations to determine the enterprise's objectives, the nature of the problem, and feasible solutions. They also include the evaluation of alternative solutions, formulation and recommended action, and suggestion $\mathrm{s}$ for and assistance in the implementation process. MAS could also require the review of the financial statements for a client. All these professional services may pose a threat to the auditor's independence. Auditors must, therefore, exercise due care to preserve their status of independence.

In providing management advisory services including training programs, supervision, review of engagements and co-contracting, those in charge should emphasize the significance of independence in mental attitude (Cook et al, 1988). The history of providing MAS to audit clients has been a thorny issue in the auditing profession. In providing MAS engagements, CPAs must be independent in fact; independence in appearance is encouraged (Wallace, 1995). CPAs must be careful that the combination of accounting, tax, and management services does not create conflict of interest or the appearance of such.

MAS threaten auditor independence. CPAs who provide them may:

- $\quad$ Become the client's advocate;

- $\quad$ Develop a stake in their client's success;

- $\quad$ Make decisions that they are later required to audit; and

- $\quad$ Become too close to management (Wallace, 1995).

There is an inherent skepticism about how close the relationship between the auditor and the management of the audit client can be without creating, in fact or in perception, a mutuality of interest that could impair the auditor's independence. As the scope of the services performed for the client by the audit firm broadens, the relationship between management and auditor becomes more proximate.

Shockley (1983) examined the effects of competition in the audit profession, management advisory services (MAS), and size of the audit firm in third-party perceptions of the external auditor independence. His results show that all the variables significantly affected third-party perceptions of auditor independence. Knapp (1985) also examined the effects of a number of variables that could affect third party perceptions of the auditor's ability to resist management pressure in an audit confect situation. His results indicate that the nature of the conflict, the financial condition of the client, and competition, affected the perceptions of the auditor's ability to resist management pressure

In cases, the audit firm even appeared to be in collusion with the management in hiding the facts. Naturally, this cast serious doubt regarding the independence of the auditors. The major factor behind such reservation was the amount that the auditors received as non-audit service (NAS) fees from these clients. Anderson, the auditor for Enron, is the best example, which got big amount for this matter (Flaming 2002). The collapse of Enron has left a severe dent on the reputation of the auditing profession. This has been acknowledged by the Big five accounting firms (Perry 2002).

\section{Empirical evidence of non-audit services}

The idea that auditor independence may be eroded via an increase in the auditor economic bond has long been recognized. Most attention has been directed at the possible impact on auditor independence of non-audit services. Although, concerns the impact of non-audit services on auditor independence are not new (Zeff, 2003, a, b). The economic bonding between audit firms and their clients would influence auditor independence. It may be that the level of client pressure would increase and auditor becomes less concerned with the quality of internal control (Muhammad and Karbhari, 2006).

Beck et al. (1988) investigate the independence issue by investigating the audit firm tenure distribution for engagements in which recurring versus nonrecurring non-audit services are performed. They report that audit tenure for companies with high recurring non-audit services is greater on average, and with smaller variance, than the audit tenure of companies with low recurring non-audit services. Thus, the results of the Beck et al. (1988) study suggest that the provision of non-audit services does increase the economic bond between auditors and their clients. Other research also suggests that the joint provision of audit and non-audit services gives rise to economic rents, which create incentives for audit firms to compromise their objectivity, e.g., waive audit adjustments, to retain audit clients (Palmrose 1986; Simunic 1984).

Sami and Zhang (2003) investigated the effect of non-audit services on the backdrop of SEC's revised rule that stressed 
perceived audit independence. They suggested that investors perceive that non-audit services impair auditors' independence.

According to Dopuch et al (2003) found that disclosure of non-audit services reduced the accuracy of investors' beliefs of auditors' independence in fact when independence in appearance was inconsistent with independence in fact.

Beattie et al (1999) conducted a questionnaire survey examined 45 economic and regulatory factors that could impair audit independence. A high level of non-audit fees was ranked as a top threat factor by users (financial journalists) and prepares (financial directors). A significant positive relationship between non-audit service fees and audit fees has been reported in the number of studies (Mc Meeking et al, 2002).

Sharma and Sidhu (2001) examined audit opinions of bankrupt companies of found that higher non-audit service fees influenced audit opinion regarding going concern.

Jenkins and Krawczyk (2000) identified four types of NAS, namely, legal services, software training, internal audit outsourcing and actuarial service. They examined how the performance of NAS influenced the perceptions of audit independence. They concluded that investors favored disclosure of NAS fees, irrespective of its materiality, whereas auditors favored such disclosures only if these were material. The result of the analysis also indicated that perceptions did not differ significantly among differing types of NAS, nor did it get affected by the levels of materiality.

Swanger and Chewning (2001) discovered significant associations between auditor independence and joint provision of non-audit services by staff separation. Jenkins and Krawczgk (2001) found that joint provision of audit and non audit services had positive impact on the perceptions of auditor independence, and also discovered that disclosure of the amount of non audit service and audit fees was preferred by investors. In the same fashion, Rayhunadan (2003) lend support that the SEC's argument that disclosure of non-audit service fees could influence shareholders voting decisions, observing that shareholders did not consider that the provision of non-audit services would threaten auditor independence even if the companies purchased very lay non-audit services from their auditors. Frankel et al (2001) provides empirical evidence on the effect of non-audit services provision on auditor independence and whether the market values fee disclosure. The authors collected fee information from 4000 proxies filed with the SEC between February and June 2001. A significant negative market reaction was found with respect to firms with the highest unexpected non-audit service fees. Looking at earnings management, the authors document that companies with higher level of non-audit service provided by their audit firms are more likely to meet or beat earning benchmarks. The authors conclude that the provision of non-audit services can threaten auditor independence.

Although there are market-based incentives for auditors to remain independent, there are also forces that potentially threaten auditor independence. Specifically, regulators are concerned about two effects of non-audit services. One is a fear that non-audit service fees make auditors financially dependent on their clients, and hence less willing to stand up to management pressure for fear of losing their business. The other is that the consulting nature of many non-audit services put auditors in managerial role (Defond et al 2002). These concerns are summarized in the following quote from the SEC regulations mandating fee disclosures (SEC, 2000). Auditor's services relationship raises two types of independence concerns. First, the more the auditor has at stake in its dealing with the audit client, particularly when the non-audit services relationship has the potential to generate significant revenues on top of the audit relationship. Second, certain types of non-audit services, when provided by the auditor, create inherent conflicts that are incompatible with objectivity.

Elder et al. (2003) investigate the relation between auditor size, non-audit services, and loan loss provision of commercial banks audited by Big 5 CPA firms. They find a positive relation between non-audit services and loan loss provisions. As a result, no evidence supports a relation between non-audit services and reduced auditor independence. Craswell et al. (2002) use a qualified audit opinion as an indicator of the exercise of auditor independence and measure fees dependence at both the national audit firm level as well as the local office level. They find that the level of auditor fees dependence does not affect auditor propensity to qualify their audit opinions.

In addition, Kinney, Palmrose and Scholz (2004) assume that restatements of previously issued financial statement reflect low-level auditor independence and do not find a statistically significant and positive association between non-audit fees and restatements.

Lee, et al, (2003) find that auditors providing both services will allow higher magnitude of income-increasing accruals, where they find no significant relationship between income-decreasing accruals and provision of non-audit services. Lu (2003) investigates whether the association between non-audit fees and auditor independence is moderated by the level of engagement risks. She finds no relationship between non-audit fees ratio and the absolute value of abnormal accruals, but a significant interactive effect of engagement risk and non-audit fees, suggesting that high engagement risks leads auditor to suppress clients' earnings management. Using types of auditor reports as a dependent variable, Hu (2001) shows that provision of non-audit service is related to the type of audit report and the change of auditors. The study 
further indicates that the likelihood of auditor change becomes lower as the CPA firm renders both services, implying that auditor independence may be affected.

Joe (2003) examines if auditors are more likely to issue going-concern modified opinions when the client has the subject of negative press coverage prior to the date of the audit opinion. The results show that negative press coverage leads the auditor to modify the audit opinion. Thus, using opinion type as a proxy also suffers from measurement error.

More recent; questionnaire survey of audit firms and listed companies in the Kingdom of Bahrain to investigate the perceptions on the issue of auditors' independence with regard to rendering non-audit services (NAS0) by Lal Joshi at al, (2007). The results of auditors and client executives support the proposition that independence is impaired if the auditor also renders non-audit services. However, most respondents from both groups indicated that NAS provided by company auditors affects the auditor independence to a limited extent only, and opine that such services should not be prohibited. Most listed companies obtain NAS from their company auditors, but the NAS fee ratio to audit fees is not high. Auditors and listed companies perceive that independence is not at all compromised or tends to be compromised to a limited extent for 15 types of NAS. The perceptions differed based on the size, non-audit fees and foreign operations for some of the NAS.

\section{Reaction to non-audit services}

After several scandals mainly in international dimensions several professionals and academics took reaction regarding to non-audit services. They attempt to clarify the nature of non-audit services as well as re defined it. The main question is how much they reached them goals?

The provision of non-audit services (NAS) by auditors to their audit clients has been regarded by regulators in the UK, the US, Australia and various other countries as a threat to auditor independence (Craswell, 1999).

Hillison and Kennelley (1988) had recommended three additional alternatives to a total prohibition of NAS provision to audit clients: (i) offer NAS to non-audit clients only; (ii) prohibit certain types of NAS; or (iii) permit all types of NAS with full disclosure requirements. They alleged that although prohibiting all NAS would produce the greatest positive impact on perceptions of auditor independence, it would be the most drastic action. They favored permitting all types of NAS with full disclosure because it would create the least resistance from practitioners, avoid companies' rejection on disclosure, and it would possibly be effective in monitoring audit clients' acquisition of NAS. Although a conflict of interest might arise from the joint provision of audit and non-audit services to audit clients, it might be inappropriate to prohibit accounting firms from offering non-audit services if this issue is observed from the 'business efficiency' perspective (Chandler and Edwards, 1996, p.26). Fearnley and Beattie (2004) reviewed prior studies and concluded that there is no need for total prohibition of joint provision of audit and NAS, as the dilemma could be overcome by the following suggestion: "more transparency about how firms manage the conflicts of interest that NAS provision creates; whether audit partners are rewarded for earning NAS; and the nature of the NAS being provided" Additionally, audit committees should play their role in approving the provision of NAS.

After the Enron collapse, the Coordinating Group on Audit and Accounting issues (CGAA) set up in 2002, put forward a number of suggestions, including for example that "there should be a strong presumption against providing internal audit services other than an exceptional circumstances" (CGAA, 2003). The CGAA found that then existing aggregate figures for non-audit services do not provide sufficient information to reassure investors and others about an auditor's independence, in the light of the significant volumes of non-audit being done.

The US Securities and Exchange Commission issued its final rule, strengthening the Commission's requirements become effective for periodic annual filings about non-audit services for the first fiscal year ending after December 15, 2003(SEC, 2003).

The UK combined code on corporate governance (FRC, 2003) acknowledging the importance of non-audit service fees in maintaining audit independence, requires that the audit committee should develop, and recommend to the board, the company's policy regarding purchase of non-audit service from the auditors. It is also requires annual reports to explain how, in the presence of non-audit service, audit independence has been safeguard.

The APB (2004) has issued five ethical standards, one of which directly relates to non-audit services and identifies numbers of threats to independence and suggests safeguards in those situations. Non-audit service fees related measures include prohibition on providing tax services to an audit client, which involves acting as an advocate for the client before an appeals tribunal of the financial statements. Also the APB ethical standards allow purchase of non-audit services only if a member of client has the capability to make independent judgments and decisions on the basis of the information provided on consequently, which involves the auditor in exercising a function that is the responsibility of the management. 
In Europe, the Wanters Ruling of the European Court of Justice, by which national law can forbid lawyers for working with auditors, in order to protect the proper practices of the legal profession, has been followed by a different proposal for a Directive on Professional Services in the Market (E.C. 2004).

Levitt (2000) the Chairman of the SEC stated that he had asked SEC staff to prepare a rule making initiative related to the expanded non-audit services offered to public company audit client. He noted that the initiative would address fundamental public policy questions, including whether there should be limits on the types of services that an auditor can render to public audit client, how firms should be structured to ensure independence, and whether firms should be permitted to affiliate with entities that the firms themselves would not be allowed to provide to those clients.

\section{Conclusion}

In the weakness of the Enron and so many large companies bankruptcy regulates taken actions to curtail auditor provided non-audit services. These actions are based on the premises that non-audit service fees impair auditor independence by making the auditor economically dependent on the client and that the consulting nature of non-audit services reduces the auditor's objectivity.

However, on one hand according to agency theory managers looking for self-interest in companies and they desire to reach them interest, in the other hand auditor may have economical interest in the clients company, so managers simply offering non-audit service and auditors accepts because of them benefits, because of unclear regulation they are practicing audit services as well as non-audit services.

In short, evidence suggests that although auditors have market based incentives to remain independent, auditor independence may be threaten when an auditor provide non-audit services to their clients and is reasonable that the non-audit services actually impair independence. However, some professional and academic took action to clarify and limited non-audit services but it seemed not much enough; thus, national and international professions should be redefined accounting and auditing regulation as well as scanted new regulation regarding to no-audit services and giving clear picture about that services to auditors as well as investors, and heavy penalties, to whom overriding these regulation.

\section{References}

Abu Bakar, A,. Bdul Rahman, A., and, Abdul Rashid, H. (2005). Factors Influencing Auditor Independence: Malaysian Loan Officers' Perceptions, Managerial Accounting, Vol. 20, No. 8, pp: 804-822.

AICPA. (1988). Code of Professional Conduct: Rule 100, American Institute of Certified Public Accountants, Available at: www.aicpa.org

Arens, A., Loebbecke, J., Iskandar, T., Susela, S., Isa, and Boh, M. (1999). Auditing in Malaysia: An Integrated Approach, Prentice-Hall, Selangor.

Ashbaugh, H. (2004). Ethical Issues Related to the Provision of Audit and Non-Audit Services: Evidence from Academic Research, Journal of Business Ethic, Vol.52, pp: 143-148

Ashbaugh, H. Lafond and Mayhew. (2003). Do Non-Audit Services Compromise Auditor Independence? Further Evidence, Accounting Review, Vol.78, No.3, pp: 611-639.

Auditing Practice Board (APB). (2004). Ethical standards, London: Financial Reporting Council Australian Society of Certified Practicing Accountants and the Institute of Chartered Accounting in Australia (2001). Statement of Auditing Practice AUP 32, Audit Independence in Auditing handbook, Volume 2 of the Accounting and Auditing handbook.

Bartlett, R.W. (1993). A Scale of Perceived Independence: New Evidence on an Old Concept, Accounting, Auditing \& Accountability Journal, Vol. 6 No.2, pp. 52-67.

Beattie, V. Fearnley and Brandt, R. (1999). Perception of Auditor independence: UK Evidence, Journal of International Accounting, Auditing and Taxation, Vol. 8 No.1, pp: 67-107.

Beck, P., Frecka, T., and Solomon, I. (1988). An Empirical Analysis of the Relationship between MAS Involvement and Auditor Tenure: Implications for Auditor Independence, Journal of Accounting Literature, Vol. 7, pp: 65-84.

Brandon, D., Crabtree, A., and Maher, J. (2004). Non-Audit Fees, Auditor Independence and Bond Ratings, Auditing: A Journal of Theory and Practice, Vol. 23, No. 2, pp. 89-103.

Brierley, J and Gwilliam, D. (2003). Human Resource Management Issues in Audit Firms: A Research Agenda, Managerial Auditing Journal, Vol. 18, No. 5, pp. 431-438.

Chandler, R., Edwards, J., and Anderson, M. (1993). Changing perceptions of the role of the Company Auditor: 1840-1940, Auditing and Business Research, Vol. 23, No. 92, pp: 443-459.

Church, B and Zhang, P. (2002). Independence in Appearance: Non-auditing Services and Auditor Fee Disclosures, Working Paper, Toronto University. 
Citron, D. (2003). The UK's Framework Approach to Auditor Independence and The Commercialization of The Accounting Profession, Accounting, Auditing and Accountability Journal, Vol. 16, No. 2, pp. $244-272$.

Cook, J.W and Winkle, G. (1988). Auditing, Houghton Mifflin, Boston, MA,.

Coordinating Group on Audit and Accountability (CGAA). (2003). Final Report to Secretary of State for Trade and Industry and the Chancellor of Exchequer, URN 03/567

Crasewell, A., Stokes, D., and Laughton, J. (2002). Auditor Independence and Fees Dependence, Journal of Accounting and Economics, Vol. 33, pp: 253-275.

Craswell, A. T. (1999). Does the Provision of Non-audit Services Impair Auditor Independence, International Journal of Auditing, Vol. 3, pp: 29-40.

Cullinan, L. (2004). Enron as A Symptom of Audit Process Breakdown: Can the Sarbones - Oxley Act Cure the Disease, Critical Perspectives on Accounting, Vol. 15, No. 617, pp. 853-864.

De Angelo, L.E. (1981). Auditor Independence, Low Balling, and Disclosures Regulation, Journal of Accounting and Economics, Vol. 3, pp: 183-199.

Defond, M. Raghunandan and Subramangam, K. (2002). Do Non-Audit Services Fees Impair Auditor Independence? Evidence from Going Concern Audit Opinions, Journal of Accounting Research, Vol. 40, pp: 1247-1273.

Dopuch, N., King, R., and Schwartz, R. (2003). Independence in Appearance and In Fact: An Experimental Investigation, Contemporary Accounting Research, Vol. 20, No. 1, pp: 279-114.

E.C. (2004) Prepared For A Directive of The European Parliament and Council on Statutory Audit. Commission Recommendation, 2004/177

Elder, R., Zhou, J., and Chen, K. (2003). Non-audit Services and Earnings Management by Commercial Banks, Working paper.

Elliott, R.K. and Jacabson, P. (1992). Audit independence: Concept and Application, the CPA journal, Vol. 62, No. 3, pp. 34-39.

Fearnley, S. and Beattie, V. (2004). The Reform of the UK's Auditor Independence Framework after the Enron Collapse: An Example of Evidence Based Policymaking, International Journal of Auditing, Vol. 8, pp: 117-138.

Flaming, L. (2002). Do Non-audit Service Affect Investor Judgment?, Evidence Using Auditor Fee Proxy Disclosures, university of Oklahoma, Working paper.

Flint. D. (1988). Philosophy and Principles of Auditing: An introduction, London, Macmillan Education LTD.

Frankel, R., Johnson, M., and Nelson, K. (2001). Auditor Independence and Earning Quality, Working paper, (Stanford University).

FRC. (2003). The Combined Code on Corporate Governance, Available at www.FRC.org.UK

Ghosh, A. and Moon, D. (2005). Auditor Tenure and Perceptions of Audit Quality, Accounting Review, Vol. 80, No. 2, pp. 585-612.

Gul, F, and Tsui, J. (1992). An Empirical Analysis of Hong Kong Bankers' Perceptions of Auditor Ability to Resist Management Pressure in an Audit Conflict Situation, Journal of International Accounting, Auditing and Taxation, Vol. 1, No.2, pp: 177-190.

Gul, F. (1989). Bankers' Perceptions of Factors Affecting Auditor Independence, Accounting, Auditing \& Accountability Journal, Vol. 2, No.3, pp. 40-51.

Gwilliam, D. (2003). Audit Methodology, Risk Management and Non-Audit Services, London, The Institute of Chartered Accountants, England and Wales.

Higson, A. (2003). Corporate Financial Reporting: Theory and Practice, London: Sage Publication.

Hillison, W. and Kennelly, M. (1988). The Economics of non-audit services, Accounting Horizons, Vol. 2, No. 3, pp: $32-40$.

Hu, C,N. (2002). The Association between Non-audit Services and Auditor Independence, Master thesis, National Taipei University.

IFAC. (2001). IFAC Code of Ethics for Professional Accountants, International Federation of Accountants.

Independence Standard Board (ISB). (2000). Exposure Draft (Ed00-2). Statement of Independence Concepts: A Conceptual Framework for Auditor Independence, New York, NY.

Jenkins. G, and Krawczy, K. (2000). The Relationship between Non-Audit Services and Perceived Auditor Independence, 
SSRN (working Paper) available at: www.ssrn.com

Joe, J.R. (2003). Why Press Coverage of a Client Influences the Audit Opinion, Journal of Accounting Research, March, pp: 109-133.

Karnish J. and Levine, B. (2004). Discipline with Common Agency: The Case of Audit and Non-Audit Services, Accounting Review, Vol.79, No.1, pp: 173-200.

Kinney, W., Palmrose, Z., and Scholz, S. (2004). Auditor Independence, Non-audit Service, and Restatement: Was the U.S. Government Right? Journal of Accounting Research, 561-588, (June 2004).

Knapp, M. (1985). Audit Conflict: An Empirical Study of The Perceived Ability of Auditors to Resist Management Pressure, the Accounting review, pp: 202-211.

Kosmala, K. (2003). The True and Fair View Construct in the Context of Publish Transaction Economy: Some Local Insights, European Accounting Review, Vol. 12, No. 3, pp. 465-487.

Lal Joshi. P, Wayne G. Bremser, J. Hemalatha, and Jawaher Al-Mudhaki. (2007). Non-audit Services and Auditor Independence: Empirical Findings from Bahrain, International Journal of Accounting, Auditing and Performance Evaluation (IJAAPE). Vol. 4, No. 1, pp: 89-107.

Lee, A. (1993). Corporate Audit theory, Devon, Chapman and Hall.

Lee, C. R., Xu, C., and Chen, C. (2003). The Study of Non-audit Service and Abnormal Accruals, Accounting Review, Vol. 37, pp: 1-30,

Levine, C. and Karnish, L. (2000). Discipline with Common Agency: The Case of Audit and Non-Audit Services, (Working paper, Duke University).

Levitt, A. (2000). Renewing the Covenant with Investors, University Center for Law and Business, Working paper.

Lu, C. W. (2003). The Effect of Non-audit Fees and Engagement Risk on Auditor Independence, Master thesis, National Taiwan University.

Mautz, R.K. and Sharaf, R. (1964). The Philosophy of Auditing, American Accounting Association, Sarasota, FL.

Mc Meeking, Pope, K and Peasnell. (2002). The Determinants of the UK Big Six Premium, (working paper, University of Exeter).

Mednick, R. ( 1990). Independence: let's Get Back to Basics, Journal of Accountancy, Vol. 169,January, pp. 86-93.

Muhamad, Z., and Karbhari, Y. (2006). Audit, Non-Audit Services and Auditor Independence, Staff Paper, Center of Excellence for Applied Financial and Accounting Studies Faculty of Economic and Management (University of Putra Malaysia).

Olazabad, A and Alwer, E. (2001). Independence and Public Perception: Why We Need to Care? Journal of Accountancy, pp: 69-71.

Orren, G. (1997). The appearance Standard on Audit Independence: What We Know and What We Should know? A Report Prepared on Behalf of the AICPA in Connection with the presentation to the Independence Standard Board.

Palmrose, Z. (1986). The Effect of Non-audit Services on the Pricing of Audit Services: Further Evidence, Journal of Accounting Research, Vol. 24, pp: 405-411.

Pany, K and Reckers, P. (1988). Auditor Performance of MAS: A Study of Its Effects on Decisions and Perceptions, Accounting Horizons, June, pp, 31-8,

Perry, M. (2002) First Big Five Move to defend Profession after Enron, available at: www.accountancyage.com Public Oversight Board (POB). (2000). The Panel on Audit Effectiveness Report and Recommendations (CT, POB).

Quick, R. and Rasmussen, W. (2005). The Impact of MAS on Perceived Auditor Independence - Some Evidence from Denmark, Accounting Forum, Vol. 29, pp: 137-168.

Raghunandan, K. (2003). Non-Audit Services and Shareholders Ratification of Auditors' Appointments, Auditing: A Journal of Practice and Theory, Vol. 22, No. 1, pp: 155-163.

Sami, H and Zhang, Y. (2003). Do Non-audit Service Impair independence Perceived by investors?, Temple University, Working Paper.

Securities and Exchange Commission (SEC). (2000). Revision of the Commission's Auditor Independence Requirements, (Releases No. 33-79919) (SEC, Washington, DC).

Sharma, D and Sidhu. (2001). Professionalism Vs. Commercialism: the Association Between Non Audit Services and Audit Independence, Journal of Business Finance and Accounting, Vol. 28, pp: 595-617 
Shockley, R.A. (1983). A Behavioral Investigation of Supplier Differentiation on the Market of Audit Services, Journal of Accounting Research, Vol. 21, Autumn, pp. 545-64.

Shockley, RA. (1981). Perceptions of Auditors' Independence: An Empirical Analysis, The Accounting Review, No.4, pp. 785-800.

Simunic, D. (1984). Auditing, Consulting, and Auditor Independence, Journal of Accounting Research, Vol. 22, pp: 679- 702 .

Stevenson, J.E. (2002). Auditor Independence: A Comparative Descriptive Study of The UK, France and Italy, International Journal of Auditing, Vol. 6, pp. 155-182.

Sucher, P. and Maclullich, K. (2004). A Construction of Auditor Independence in the Czech Republic: Local Insights, Accounting, Auditing and Accountability Journal, Vol. 17, No. 2, pp. 276-305.

Swanger, S. and Chewning, E. (2001). The Effect of Internal Audit Outsourcing of Financial Analysts Perceptions of External Auditor Independence, Auditing: A Journal of Practice and Theory, Vol. 20, No. 2, pp. 115-129.

Teoh, H.Y. and Lim, E. (1996). An Empirical Study of the Effects of Audit Committees, Disclosure of Non-audit Fees and Other Issues on Audit Independence: Malaysian Evidence, Journal of International Accounting, Auditing and Taxation, Vol. 5 No.2, pp. 231-48.

Terry, E. (1996). Revisiting Independence, The Journal of Auditor, Vol. 53, No. 6, pp: 66-70.

Wahdan, Spronck, P., Ali, H., Waassen, E., and Hernick, H. (2005). Auditing in Egypt: A Study of Challenges, Problems and Possibility of An Automotive Formulation of Auditors Report, available at: WWW.CS.unimass.ni/p.spronck/rules.Wahdan2005.pdf

Wallace, W.A. (1995). Auditing, South-Western College, Cincinnati, OH,.

Zeff, A. (2003a). How the US Accounting Profession Got Where It Is Today: part I, Accounting Horizons, Vol. 17, pp. $189-205$.

Zeff, A. (2003b). How the US Accounting Profession Got Where It Is Today; part II, Accounting Horizons, Vol. 17, pp. 267-286. 